\title{
The Efficacy of Boarding System University in Producing Competent Graduates for the Era of Industry 4.0
}

\author{
Hamid Fahmy Zarkasyi ${ }^{1}$, Ihwan Mahmudi ${ }^{2}$, Ahmad Saifulloh $^{3}$, Heru Saiful Anwar ${ }^{4}$, \\ Syamsuddin Arif ${ }^{5}$, Syarifah ${ }^{6}$ \\ \{hfzark4@gmail.com 1 , ihwanm@unida.gontor.ac.id ${ }^{2}$, saif@unida.gontor.ac.id $^{3}$, \\ anwarherusaiful@gmail.com ${ }^{4}$, tegesauge@gmail.com ${ }^{5}$, syarifah@unida.gontor.ac.id $^{6}$ \} \\ University of Darussalam Gontor, Jalan Raya Siman Ponorogo $0^{1,2,3,4,5,6}$
}

\begin{abstract}
The era of disruption has brought about a change in the competencies of university graduates. According to the World Economic Forum 2016, there are ten competencies. This study aims to examine the extent to which the University of Darussalam Gontor (UNIDA) with its boarding system inculcates the ten competencies to its students. The object of this research is all students' activities. It is a case study that employs a qualitative approach. The data analyzed by descriptive analysis techniques. The result shows that the Competencies are inculcated through student activities as knowledge management in their curriculums. The student learns cognitive flexibility, problem-solving and critical thinking formally in the classroom but subsequently, they are improved informally and non-formally in dormitory activities. Other competencies are taught through student activities informally and non-formally. The informal curriculum consists, among other things of the student organization. The non-formal curriculum is embedded in Five Spirit of university life.
\end{abstract}

Keywords: Boarding System, formal curriculum, informal curriculum, non-formal curriculum.

\section{Introduction}

The term "Industry 4.0 " or the $4^{\text {th }}$ Industrial Revolution (4IR) recently becomes a topical debate among scholars and academia. While the First, Second and Third Industrial Revolution used steam power, electric power, electronics and information technology for industry respectively, the 4IR is characterised by computing capacity with artificial intelligence to store big data. It contributes to unclear lines between physical, digital, and biological spheres [1]. As a result, the world changes rapidly leading to the era of disruption and societal turmoil [2]. Hence, this influences the world of politics, economics, social, culture, industry, and education.

In the educational context, Higher Education (HE) has to adapt to this fast-shifting global economy since it has a critical role to play in assisting societal transitions for the 4IR [3]. To respond to 4IR, higher education requires substantial changes to the formal curriculum including science and technology, biology, chemistry, environmental science, physics, allowing students to develop their capacity in the unpredicted change of the world [4]. In Singapore, HE systems are designed to internationalise its graduates and create more globally practical knowledge and 
connected citizenry [5]. It is done by accelerating and intensifying students' role in transnational mobilities and connectivity to respond to 4IR challenges [6]. To illustrate, the National University of Singapore and the University of Yale jointly create a comprehensive curriculum based on conversations between Asia and the West to bridge the gap between the sciences and the social sciences and develops more competent graduates who know how to learn [7]. In South Africa, HE treats human learning as a complicated system in which adaptive behaviour is present. Therefore, HE needs to deploy pedagogy that produces creative thinkers with practical skills to respond to such radical and sudden changes [8]. Chinese universities strive to develop the culture of creativity and innovation and initiate efforts to cultivate connections between universities and industry [9]. It is supported by the Ministry of Education (MOE) which has issued specific policies to support innovation and entrepreneurship, such as allowing students to take one year off to pursue an entrepreneurial venture [3].

Similar to previous initiatives, the University of Darussalam Gontor (UNIDA Gontor) is endeavouring to enhance the quality of education in the context of addressing the challenge of 4IR. However, as the only university that employs full Islamic boarding system in Indonesia, University of Darussalam Gontor has its strategy. It is because Islamic boarding system is unique to Indonesian Islamic educational institutions existed since pre-colonialism era where Muslims learn their religion and other knowledge within boarding system under the direction of teachers and their spiritual leader is known as Kiai [10]. Then, boarding system is defined as the Islamic education institution with full boarding system where Kiai is considered as a central figure, mosque as the centre of activities, and Islamic teaching under Kiai's supervision is the main program [11], [12]. Thus, the boarding system university is the higher educational institution that employs the boarding system in its educational activities.

As a university-based boarding system, University of Darussalam Gontor has a unique endeavour in preparing its graduates for 4IR. The university believes that teaching the top ten skills to its students as suggested by 2016 World Economic Forum (WEF) is one of strategy to deal with the challenge of 4IR. Those skills are complex problem solving, critical thinking, creativity, people management, coordinating with others, emotional intelligence, judgment and decision making, service orientation, negotiation, cognitive flexibility [13]. This research is aimed at investigating the efficacy of the University of Darussalam Gontor as university-based boarding system in teaching the previous top ten skills in the context of creating graduates for 4IR.

\section{Research Methodology}

To investigate the efficacy of boarding system university education in inculcating ten competencies, we employ a qualitative approach with a case study as the research strategy and design [14]. The unit of analysis in this research is the curriculum design and the whole student activities on the campus. The data were collected by observation, interview, and documentary method, then analysed using interactive analysis model which contains three components; data reduction, data presentation, and conclusion or data verification which is done together with the process of collecting data interactively by cycle process [15]. 


\section{Research Findings}

The efforts of the University of Darussalam Gontor in creating graduates who can compete with others in 4IR era started from its educational objectives. The whole educational programs within this university are intended to produce graduates who have Islamic faith, good characters, broad knowledge, and ten skills as suggested by 2016 WEF. Thus, the full boarding system here becomes a super system comprising formal, non-formal, and informal education. These three interrelated educations require a specific curriculum design as the blueprint of the education process. In this context, the curriculum in the perspective of boarding system is not only the number of courses taught in the classroom as formal curriculum but also the whole activities within full boarding system campus as informal and non-formal curriculum [16].

\subsection{Formal Curriculum}

The formal curriculum is characterised as a systematic and organised education model, structured and managed by specific laws and norms with specific objectives and methodology [17]. Three main strategies deliver the formal curriculum at the University of Darussalam Gontor: integrating sciences with religious studies; developing an innovative method of teaching; involving values and spirituality into teaching and learning process.

Regarding the first strategy, University of Darussalam Gontor contends that Islamic studies are the mother of knowledge developed by all faculties at the University of Darussalam Gontor. Therefore, the curriculum design for all faculties and departments follow this model as the principle of knowledge management.

\begin{tabular}{|c|c|c|c|}
\hline $\begin{array}{l}\quad \text { Social Sciences } \\
\text { Psychology } \\
\text { Civic education } \\
\text { World History } \\
\text { Indonesia history } \\
\text { Education } \\
\text { Bahasa Indonesia } \\
\text { Sociology } \\
\text { Geography }\end{array}$ & $\begin{array}{l}\quad \text { Sciences } \\
\text { Matematika } \\
\text { Physic } \\
\text { Biology } \\
\text { Arithmetic } \\
\text { Mantiq (Logic) }\end{array}$ & $\begin{array}{l}\quad \text { English } \\
\text { Reading } \\
\text { Grammar } \\
\text { Composition }\end{array}$ & \begin{tabular}{l}
\multicolumn{1}{c}{ Arabic } \\
Muthalaah \\
Nahw Sharf, \\
Balaghah, T.Adab \\
Insya' \\
Mahfuzat \\
Tarjamah \\
Imla'
\end{tabular} \\
\hline \multicolumn{4}{|c|}{ Islamic Studies } \\
\hline $\begin{array}{l}\text { Al-Tauhid } \\
\text { Al-Qur'an \& Tajwid } \\
\text { Tafsir }\end{array}$ & $\begin{array}{l}\text { Islamic History } \\
\text { Ayat al-Ahkam } \\
\text { Comparative Religion }\end{array}$ & $\begin{array}{l}\text { Mazahib Fiqhiyya } \\
\text { Ushul Fiqh } \\
\text { Fiqh } \\
\text { al-Din al-Islami (Is }\end{array}$ & $\begin{array}{l}\text { Mustholahul Hadith } \\
\text { Faraidh } \\
\text { Al-Hadith } \\
\text { amic worldview) }\end{array}$ \\
\hline
\end{tabular}

Fig.1. Chart of formal curriculum design at University of Darussalam Gontor 
The Figure 1 illustrates that Islamic studies become the foundation of other disciplines including sciences, social science, humanities, and linguistics. It means that all students in all faculties study Islam as the basis of their journey in seeking knowledge. As a result, students will have cognitive flexibility after spending some years of their time in university because they are trained to study every unit of study with a multidisciplinary approach. For example, a student at the faculty of economics studies accounting not only from the perspective of economics but also from an Islamic teaching perspective. This model of knowledge management successfully gives students a more flexible future career.

The design as mentioned earlier of formal curriculum could be successful if the effective and innovative methods of teaching are employed during its delivery. For this matter, all academic staff at the University of Darussalam Gontor should internalise these methodological principles: the method of teaching is more important than the subject; the lecturer is more important than the method; the spirit of the lecturer is the essential thing in the teaching-learning process. Based on these principles, lecturers at the University of Darussalam Gontor are not merely the one who transfers the knowledge to students, but they are the role model for students in seeking the knowledge and exemplary figure for them in terms of their religiosity, sound logic, attitude, and behaviours. It contributes to the positive and supportive milieu of study allowing students to have positive energy and greediness in seeking the knowledge. The findings of this research confirm this argument that most lecturers can make students study independently and acquire sound logic, right attitude and behaviours.

Also, University of Darussalam Gontor implements Indonesian Qualification Framework (IQF) as the basis of the curriculum design and its delivery. The implementation of IQF curriculum aims to guarantee the achievement of learning outcome by students after the learning process. One of the critical things in IQF curriculum is student-centred learning. It means that lecturers give various structured assignments to students during their learning process individually or in a group. By this method, students will have the problem-solving skill and achieve it after completing the assignments. Subsequently, students are required to present the result of their assignments in front of other students and discuss them to gain feedback. Within this process, students learn critical thinking and cognitive flexibility since they have to debate, argue, and refute their arguments.

Referring to the results of interview and observation, it turns out that the boarding system university-based formal curriculum as mentioned earlier could assist students in acquiring skills of cognitive flexibility, complex problem solving, and critical thinking.

\subsection{Informal Curriculum}

The informal curriculum is a result of osmosis process between students and their environment [17]. In this context, University of Darussalam Gontor attempts to design the 
informal curriculum within boarding systems as follow: all kind of extramural activities are provided for Students; all activities are intended to enhance the students' potentiality; students are given all opportunity to manage their own lives in the campus; all activities provided should be oriented towards education.

In the practical domain, the informal curriculum for students at the University of Darussalam Gontor is classified into compulsory and elective activities. All students are required to participate in those necessary activities such as Public Speaking, Scout, Jama'ah Prayer, Religious talk, campus discipline, language discipline, student organisation, jogging, etc. In terms of elective activities, students are suggested to participate in the activities based on their preference in sport, religious program, and art.

\begin{tabular}{|l|}
\hline Compulsory \\
Public Speaking \\
Scout \\
Jama'ah Prayer \\
Religious talk \\
Campus discipline \\
Lang.Discipline \\
Organization \\
Jogging \\
\hline \hline Elective: Skill \\
Sewing \\
Handicraft \\
Binding \\
Electronic \\
Computer \\
Language course \\
Journalistic \\
Publication \\
\hline
\end{tabular}

\begin{tabular}{|c|c|}
\hline & $\begin{array}{l}\text { Elective: Sports } \\
\text { Football } \\
\text { Volleyball } \\
\text { Basketball } \\
\text { Takraw } \\
\text { Martial Art } \\
\text { Body Building } \\
\text { Badminton } \\
\text { Table Tennis }\end{array}$ \\
\hline \multirow{2}{*}{$\begin{array}{c}\text { INFORMAL } \\
\text { CURRICULUM }\end{array}$} & $\begin{array}{l}\text { Elective: Religious } \\
\text { Jum'iyyat al-Qurra } \\
\text { Fasting Group } \\
\text { Tahajjud Group } \\
\text { Discussion Group }\end{array}$ \\
\hline & $\begin{array}{l}\text { Elective: Art } \\
\text { Calligraphy } \\
\text { Drama } \\
\text { Music }\end{array}$ \\
\hline
\end{tabular}

Fig. 2. Chart of the design of informal curriculum at University of Darussalam Gontor

The chart in Figure 2 explains that whole student's activities at the campus are classified into compulsory and elective activities. Most activities are managed and organised by student organisations which provide a wide range of opportunities for students to be involved. 
Since there are various activities in full boarding system campus, student organisations have a significant role in managing them. Therefore, the university has many student organisations including a dormitory, University Students Union with its dozen departments, faculty-based organisations, and other organisations which have an affiliation to external organisations.

Within both compulsory and elective activities, students are allowed to take part in various activities. Therefore, they could develop their adaptation skill since it is very likely for a student to have one friend in a particular club (for example sports), but he is also very likely to be his rival in other activities such as scout activities. This condition requires students to have the ability in controlling their emotions. Furthermore, during their participation in various activities, students also learn how to manage people. It is because a student might become a leader in one activity and become a member of other activities. Thus, students learn how to coordinate with others, negotiate, and make critical decisions.

To summarise, students of the University of Darussalam Gontor have an opportunity to develop their good characters and skills by involving in many informal education programs. Those skills are creativity, people management, coordinating with others, emotional intelligence, judgment and decision making, service orientation, negotiation, and cognitive flexibility. As explained earlier, those skills are determinant factors for graduates of higher education in surviving and competing with others in the era of Industry 4.0.

\subsection{Non-Formal Curriculum}

A non-formal curriculum could be defined as an organized educational activity outside the formal curriculum [17]. As university-based boarding system, University of Darussalam Gontor organises various programs inside the campus. Those programs become effective media to teach core values of boarding System University to students. Those values are five spirits of boarding System University consisting sincerity, simplicity, self-reliance, Islamic brotherhood, freedom; the motto of modern boarding System University consisting good character, sound body, broad knowledge, independent mind; and five long term programs including education, regeneration, infrastructure, funding, welfare.

To effectively teach those core values of boarding System University, those values are displayed in many places at the campus. Besides, the rector and lecturers regularly deliver their speech explaining those values in front of the students at various activities such as public speech at the mosque, official meeting with students, briefing before certain activities, etc. Also, they become the first who internalised the core values in their daily life. It will yield favourable milieu for students in understanding the boarding system of university core values and internalising them in their life.

\section{Conclusion}

The findings of this research highlight the efficacy of boarding System University in inculcating required skills for the 4IR era. It is because boarding System University education integrates between formal, informal, and non-formal curriculum in its knowledge management. The Formal curriculum at the University of Darussalam Gontor produces students who have 
cognitive flexibility, complex problem-solving skill, and critical thinking skill. The informal and non-formal curriculum assists students to have other skills such as creativity, people management, coordinating with others, emotional intelligence, judgment and decision making, service orientation, and negotiation.

Also, the results of this study contend that required skills for the 4IR era as mentioned earlier could be achieved by students as long as they actively involved in many programs provided by the University of Darussalam Gontor.

\section{References}

[1] Klaus Schwab, "The Fourth Industrial Revolution: what it means and how to respond | World Economic Forum," www.weforum.org, 2016. [Online]. Available: https://www.weforum.org/agenda/2016/01/the-fourth-industrial-revolution-what-it-meansand-how-to-respond/. [Accessed: 04-Jan-2016].

[2] K. Schwab, No The Fourth Industrial Revolution. Geneva: World Economic Forum, 2016.

[3] N. W. Gleason, Higher Education in the Era of the Fourth Industrial Revolution, 1st ed. SIngapore: Springer Nature, 2018.

[4] B. E. Penprase, "The Fourth Industrial Revolution and Higher Education," Higher Education in the Era of the Fourth Industrial Revolution. Soka University of America, Aliso Viejo, 2018.

[5] N. W. Gleason, "Singapore's Higher Education Systems in the Era of the Fourth Industrial Revolution: Preparing Lifelong Learners BT - Higher Education in the Era of the Fourth Industrial Revolution,” N. W. Gleason, Ed. Singapore: Springer Singapore, 2018, pp. $145-169$.

[6] P. Yang and Y. Cheng, "Educational Mobility and Transnationalization BT - Higher Education in the Era of the Fourth Industrial Revolution," N. W. Gleason, Ed. Singapore: Springer Singapore, 2018, pp. 39-63.

[7] P. Lewis, "Globalizing the Liberal Arts: Twenty-First-Century Education BT - Higher Education in the Era of the Fourth Industrial Revolution," N. W. Gleason, Ed. Singapore: Springer Singapore, 2018, pp. 15-38.

[8] B. Xing, L. Marwala, and T. Marwala, “Adopt Fast, Adapt Quick: Adaptive Approaches in the South African Context BT - Higher Education in the Era of the Fourth Industrial Revolution,” N. W. Gleason, Ed. Singapore: Springer Singapore, 2018, pp. 171206.

[9] R. M. Lee and Y. (Selena) Yuan, "Innovation Education in China: Preparing Attitudes, Approaches, and Intellectual Environments for Life in the Automation Economy BT Higher Education in the Era of the Fourth Industrial Revolution," N. W. Gleason, Ed. Singapore: Springer Singapore, 2018, pp. 93-119.

[10] Z. Dhofier, Tradisi Pesantren: Studi Tentang Pandangan Hidup Kyai. Jakarta: LP3ES, 1985.

[11] A. S. Zarkasyi, Gontor \& pembaharuan pendidikan pesantren. Jakarta: Divisi Buku Perguruan Tinggi, RajaGrafindo Persada, 2005.

[12] Mastuhu, Dinamika sistem pendidikan pesantren : suatu kajian tentang unsur dan nilai sistem pendidikan pesantren /Mastuhu. Jakarta: INIS, 1994.

[13] World Economic Forum, "The Future of Jobs - Reports - World Economic Forum," 2016. 
[14] R. K. Yin, Robert K. Yin. (2014). Case Study Research Design and Methods (5th ed.). Thousand Oaks, CA: Sage. 282 pages., 5th ed. Sage, 2014.

[15] M. B. Miles, A. M. Huberman, and J. Saldaña, Qualitative Data Analysis A Methods Sourcebook, 3rd ed. Arizona State University, USA: SAGE Publications, Inc, 2013.

[16] H. F. Zarkasyi, "Modern Pondok Pesantren: Maintaining Tradition in Modern System," TSAQAFAH J. Perad. Islam, vol. 11, no. 2, pp. 223-248, 2015.

[17] A. Hamadache, "Non-Formal Education: A Definition of the Concept and Some Examples,” Prospects, vol. 21, no. 1, pp. 111-124, 1991. 